\title{
A STUDY ON ADULTERANTS OF MILK OF SELECTED COASTAL DISTRICTS OF ANDHRA PRADESH
}

\section{LayamAnitha ${ }^{*}$, Gannavarapu SaiBramari², Kalla Appala Naidu³}

1*Associate Professor, 2Subject matter expert in Biology, CHEGG India Pvt. Ltd.,

${ }^{3}$ Research Scholar, Department of Microbiology/Food Science and Technology, Institute of Science, GITAM University, Visakhapatnam

Email: layamanitha@gmail.com

\begin{tabular}{l} 
ABSTRACT \\
$\begin{array}{l}\text { Milk is a complete or whole food and biologically effective nutrient medium. Milk is } \\
\text { perishable food that supports growth of wide variety of microorganisms that cause the } \\
\text { spoilage of milk. Milk acts as transport vehicle for transmission of contaminants and } \\
\text { adulterants that affect the quality of milk in terms of adulterants such as urea, starch, } \\
\text { neutralizers etc. These agents enter milk through contaminated cattle feedstuff or can be } \\
\text { introduced into milk intentionally. Therefore, the present research study aimed to study } \\
\text { adulterants from milk supply chain of } 5 \text { coastal districts of Andhra Pradesh, India, including } \\
\text { Visakhapatnam, Vizianagaram, Srikakulam, East Godavari and West Godavari districts. } \\
\text { The milk samples were collected randomly and directly from milk producers (farmers), bulk } \\
\text { chilling centers, vendors and pasteurized milk samples from various dairy outlets. The } \\
\text { results were expressed in mean } \pm \text { standard deviation. The results were analyzed by } \\
\text { ANOVA. The milk samples analysed for adulterants among various districts have shown } \\
\text { the significant p-value for Urea, Starch, Detergent, NaCl, Sugar, Skimmed milk powder, } \\
\text { Glucose and Water. Significant p - values of analysis of various milk samples across five } \\
\text { districts indicate that milk quality is compromised and affected. The values obtained } \\
\text { confirm the same and the study concluded as milk samples of poor quality which should } \\
\text { be carefully monitored to minimize the health risks. }\end{array}$ \\
\hline
\end{tabular}




\section{Introduction}

An adulterant is a chemical substance mixed with other substances to make them of poor quality. These substances should not be contained in foods, beverages and fuels for legal or other reasons. The addition of adulterants is called adulteration. The word is appropriate only when the additions are unwanted by the recipient. Otherwise the expression would be food additive. Adulterants used as illicit drugs are known as cutting agents. The addition of toxic adulterants to food and other products that are consumed by humans results in poisoning (Singuluri and Sukumaran, 2014).

Milk is adulterated and its quality is affected and as well as other dairy products. These adulterants are low value ingredients that reduce the quality of milk and milk products. A national survey conducted in India has revealed that $70 \%$ of milk sold and consumed is adulterated by low value contaminants such as detergent, skim milk powder, water, urea, neutralizers, starch, sucrose, glucose, formaldehyde, ammonium sulphate and hydrogen peroxide etc. The Food Safety Standards Authority of India (FSSAI) conducted a national survey during the year 2011 and found that the most common adulterants detected in milk are water and detergent.

In the year $201268 \%$ of milk samples were found to be contaminants of adulterants of which $31 \%$ of milk samples were from rural areas. Among these adulterated milk samples $16.7 \%$ samples were packed or branded milk samples and the rest of the samples were sold loose from dairies. In urban areas $68.9 \%$ of milk samples were detected with adulterants like water, detergent, urea and skim milk powder. About $88 \%$ of milk in Uttarakhand was detected as adulterated. In Gujarat, $89 \%$ of milk was reported to be adulterated with glucose, sodium chloride, sucrose, ammonium sulphate at $30 \%, 46 \%, 50 \%, 96 \%$ and $100 \%$ respectively (Jivraj Makadiya and Astha Pandey, 2015). The milk samples collected from 7 different regions of Amaravathi were found to be good in quality though some adulterants were detected in one or two milk samples, they were found to be more than the standard values prescribed by Food Quality Authority of India (Hande Ashwini, 2015). The presence of high or low amounts of adulterants in milk is public health concern and fixes the poor quality of the milk (Ananya Debnath et al., 2015). In Hyderabad a study revealed that urea, neutralizers and salts were found in $60 \%$, $26 \%$ and $82 \%$ of milk samples respectively along with formalin, detergents and hydrogen peroxide at $32 \%, 44 \%$ and $32 \%$ of milk samples respectively (Singaluri and Sukumaran, 2014).

Water is an adulterant added to the milk to increase the volume but it also decreases the nutritive value of the milk. Detergents are agents added to the milk to emulsify and dissolve oil in the water and give a frothy solution and characteristic milky white colour. Urea is mixed with the milk to increase the solid not fat (SNF). The urea contributes to the white color of the milk and increases its consistency. Starch is added to the milk 
to increase its density and to prevent water detection from milk. Hydrogen peroxide is added to milk to preserve it for long time with freshness. Carbonates and bicarbonates added in the milk cause disruption in hormone function and reproduction. Sucrose is added to the milk to increase density. Sodium chloride, ammonium sulphate and neutralizers like caustic soda, sodium bicarbonate and carbonate are added to milk to increase the density and to neutralize the acidity of milk (Singuluri and Sukumaran, 2014). Other adulterants like benzoic acid, boric acid, salicylic acid, vanaspathi, formaldehyde and skimmed milk powder are frequently added to the milk for various purposes and to make consumer to believe that the milk is of good quality (Mohit Kamthania et al., 2014). A study in Punjab concluded that milk adulteration was mainly caused due to a gap between demand and supply and unhygienic practices of milking, handling, transport and post pasteurization contamination (Ritu Tangri and Anshu, 2014).

Adulteration of milk may be intentional or unintentional. Sometimes adulteration may be incidental contamination caused due to ignorance, negligence or poor practices. The adulteration of milk is otherwise known as economic adulteration that decreases the quality of milk which may be reflected on milk based products. From the literature it is evident that no studies have been reported from south of India and hence present study was undertaken to test the adulteration of milk both in the selected commercial and vendors milk supplies.

\section{Methodology}

Detection of adulterants in milk samples:

A standard milk adulteration kit manufactured by HIMEDIA laboratories, Mumbai, India was used. The milk samples were tested for the following adulterants - urea, starch, neutralizers $\left(\mathrm{NaHCO}_{3}, \mathrm{Na}_{2} \mathrm{CO}_{3}, \mathrm{Na}(\mathrm{OH})_{2}, \mathrm{Ca}(\mathrm{OH})_{2}\right.$, detergents, sodium chloride and skim milk powder (smp) etc. A standard milk adulteration kit manufactured by HIMEDIA laboratories, Mumbai, India was used. The milk samples were tested for the following adulterants - urea, starch, neutralizers $\left(\mathrm{NaHCO}_{3}, \mathrm{Na}_{2} \mathrm{CO}_{3}, \mathrm{Na}(\mathrm{OH})_{2}\right.$, $\left.\mathrm{Ca}(\mathrm{OH})_{2}\right)$, detergents, sodium chloride, skim milk powder, sugar, glucose and water (Awan et.al., 2014).

\section{Urea detection test}

To $2 \mathrm{ml}$ of milk in a sample test tube $2 \mathrm{ml}$ of urea reagent -1 was added and mixed. Appearance of distinct yellow color indicated the presence of urea in milk.

\section{Starch detection test}

To $3 \mathrm{ml}$ of milk sample in test tube little amount of water was added and boiled for a few minutes and cooled. To this milk sample 3 drops of starch reagent1 (ST-1) was added and mixed. Appearance of blue color indicates the presence of starch in the milk.

\section{Neutralizers detection method}

About $5 \mathrm{ml}$ of milk sample was taken in test tube and 4 drops of neutralizers reagent -1 (N-1) was added and mixed well. Appearance of red color 
(or deep rose color) indicates the presence of neutralizers in milk.

\section{Detection of detergents}

About $5 \mathrm{ml}$ of milk sample was taken in a test tube and 5 drops of detergent-1 reagent (DT-1) was added and mixed well. Appearance of dark purple color indicates the presence of detergent.

\section{Detection of sugar}

About $5 \mathrm{ml}$ of milk sample was taken in test tube to this few drops of sugar reagent -1 (S-1) and 4 drops of sugar reagent -2 (S-2) were added and mixed. The contents were placed in boiling water bath for 2 minutes. Appearance of red color indicates the presence of the sugar in milk.

\section{Detection of Sodium chloride}

To $2 \mathrm{ml}$ of milk in test tube 2 drops of sodium chloride reagent- 1 and $2 \mathrm{ml}$ of sodium chloride reagent- 2 were added and contents were mixed. Appearance of an yellow precipitate was indicates presence of salt in the milk

\section{Detection of skim milk powder}

To the milk sample nitric acid was added and appearance of violet color indicates the presence of skim milk powder (SMP). Absence of SMP indicates yellow colored milk.

\section{Statistical analysis:}

The data obtained for various milk samples collected from various districts was analyzed by two way ANOVA and P- value was obtained by using SPSS software (version 20) (Awal Shihabul et al., 2016).

\section{Results and Discussion}

\section{Detection of adulterants in raw and chilled milk samples:}

The mean values of Adulterants in positive raw milk samples obtained from various districts were given in Table 1. In Visakhapatnam, highest mean value was reported for Urea $(50 \pm 0)$ and lowest mean value was reported for Skimmed Milk Powder or SMP $(4 \pm 1)$. In Srikakulam highest mean value was reported for Urea $(50 \pm 0)$ and lowest mean value for

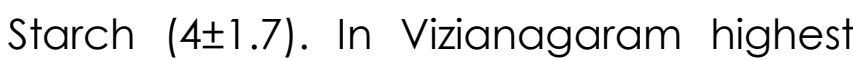
mean value was reported for Urea $(46 \pm 1.7)$ and lowest mean value was reported for Starch (4 \pm 2 ). The Adulterants like detergents, sugar, SMP and glucose were not detected in raw milk samples of Vizianagaram. In East Godavari highest mean value was reported for Urea

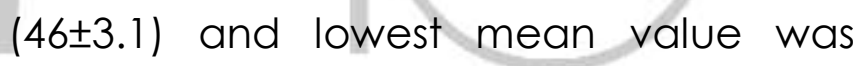
reported for $\mathrm{NaCl}$ (43 \pm 7.0$)$. Starch, detergent, sugar, SMP and glucose were not detected in milk samples of both East and West Godavari districts. In West Godavari highest mean value was reported for Urea $(48 \pm 0)$ and lowest mean value for $\mathrm{NaCl}(40 \pm 10.6)$. The comparison of mean values for each Adulterant among districts was carried out to obtain $p$-value. The $p$-value was found to be significant for Urea, Starch, Detergent, $\mathrm{NaCl}$, Sugar, SMP, Glucose and Water and non-significant for Neutralizers. The mean values of adulterants in raw milk samples were shown in figure 1. 
Table 1: Mean values of adulterants in positive raw milk samples in various regions

\begin{tabular}{|c|c|c|c|c|c|c|c|}
\hline $\begin{array}{l}\text { Name of the } \\
\text { adulterant }\end{array}$ & $\begin{array}{c}\text { Total } \\
\text { number } \\
\text { of } \\
\text { samples }\end{array}$ & $\begin{array}{l}\text { Visakhapatna } \\
\text { m } \\
\text { ( sd mean+/- } \\
\text { positive } \\
\text { sample) }\end{array}$ & $\begin{array}{c}\text { Srikakulam } \\
\text { ( sd mean+/- } \\
\text { positive } \\
\text { sample) }\end{array}$ & $\begin{array}{c}\text { Vizianagaram } \\
\text { (\% of positive } \\
\text { sample) }\end{array}$ & $\begin{array}{c}\text { East Godavari } \\
(\text { mean+/- } \\
\text { positive sample })\end{array}$ & $\begin{array}{c}\text { West } \\
\text { Godavari } \\
\text { (mean+/- sd } \\
\text { positive } \\
\text { sample) }\end{array}$ & p-Value \\
\hline Urea & 50 & $50 \pm 0$ & $50 \pm 0$ & $46 \pm 1.73$ & $46 \pm 3.05$ & $48 \pm 0$ & $>0.031 *$ \\
\hline Starch & 50 & $40 \pm 4$ & $4 \pm 1.73$ & $4 \pm 2$ & ND & ND & $>0.001 *$ \\
\hline Detergents & 50 & $20 \pm 3.6$ & $45 \pm 1$ & ND & ND & ND & $>0.000 *$ \\
\hline $\mathrm{NaCl}$ & 50 & $49 \pm 1.15$ & $10 \pm 3.46$ & $43 \pm 5.13$ & $43 \pm 7.03$ & $40 \pm 10.58$ & $>0.000 *$ \\
\hline SUGAR & 50 & $20 \pm 4$ & $50 \pm 0$ & ND & ND & ND & $>0.000 *$ \\
\hline SMP & 50 & $4 \pm 1$ & $45 \pm 1$ & ND & ND & ND & $>0.000 *$ \\
\hline
\end{tabular}

*-Significant; ND- not detected

\section{Mean values of adulterants of raw milk samples}

\section{in various regions}

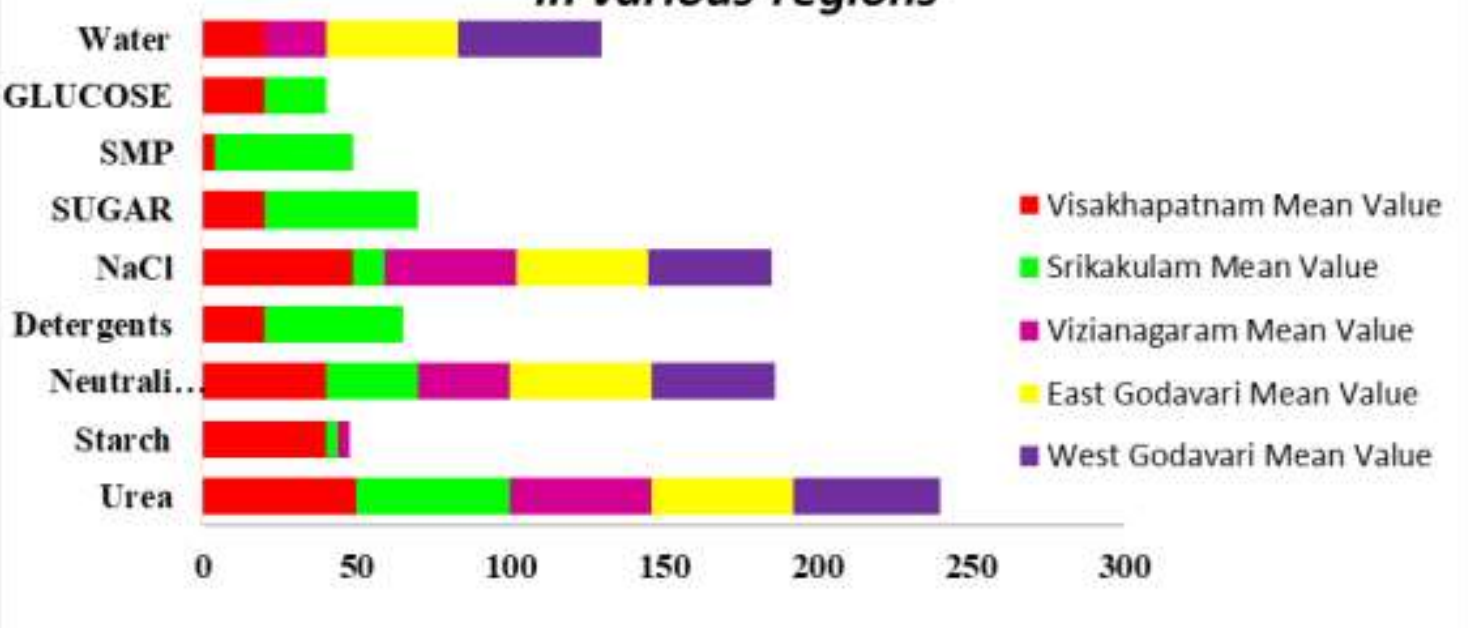

Figure 1: Mean values of adulterants of raw milk samples in selected districts

The mean values of Adulterants in positive chilled milk samples in various districts were given in Table 2. In Visakhapatnam,
Srikakulam, Vizianagaram, East and West Godavari districts highest mean value was observed for Urea. Water was 2020 November Edition | www.jbino.com | Innovative Association 
reported to have lowest mean value in Visakhapatnam, Srikakulam and East Godavari. Lowest mean value was observed for detergents in Vizianagaram $(4 \pm 2.6)$. Lowest mean value in West Godavari was observed for $\mathrm{NaCl}(2 \pm 2)$. Comparison of mean values of Adulterants among five districts was carried out to obtain p-value. Significant p-values were observed for neutralizers, detergents, $\mathrm{NaCl}$, sugar, glucose and water and non-significant for Urea and Starch. The mean values of adulterants in chilled milk samples were shown in figure 2.

Table 2: Mean values of adulterants in positive chilled milk samples of selected regions

\begin{tabular}{|c|c|c|c|c|c|c|c|}
\hline $\begin{array}{c}\text { Name of } \\
\text { the } \\
\text { adulterant }\end{array}$ & $\begin{array}{c}\text { Total } \\
\text { number } \\
\text { of } \\
\text { samples }\end{array}$ & $\begin{array}{c}\text { Visakhapatnam } \\
\text { (mean +/-sd } \\
\text { positive } \\
\text { sample) }\end{array}$ & $\begin{array}{c}\text { Srikakulam } \\
\text { (mean+/-sd } \\
\text { positive } \\
\text { sample) }\end{array}$ & $\begin{array}{c}\text { Vizianagaram } \\
\text { (mean+/-sd } \\
\text { positive } \\
\text { sample) }\end{array}$ & $\begin{array}{c}\text { EastGodavari } \\
\text { \% of positive } \\
\text { sample) }\end{array}$ & $\begin{array}{c}\text { WestGodavari } \\
\text { \% of positive } \\
\text { sample) }\end{array}$ & p-Value \\
\hline Urea & 50 & $50 \pm 0$ & $46 \pm 3.05$ & $50 \pm 0$ & $48 \pm 2$ & $48 \pm 0$ & $0.125^{\mathrm{NS}}$ \\
\hline Starch & 50 & $\mathrm{ND}$ & $\mathrm{ND}$ & $4 \pm 1.7$ & $4 \pm 2.6$ & $4 \pm 3.6$ & $0.065^{\mathrm{NS}}$ \\
\hline Neutralizers & 50 & $10 \pm 5$ & $13 \pm 7$ & $20 \pm 5.2$ & $40 \pm 5$ & $40 \pm 5.3$ & $>0.000^{*}$ \\
\hline Detergents & 50 & $\mathrm{ND}$ & $4 \pm 3.4$ & $4 \pm 2.64$ & $4 \pm 2$ & $10 \pm 3$ & $0.015^{*}$ \\
\hline NACL & 50 & $45 \pm 5$ & $9 \pm 1.7$ & $20 \pm 10$ & $20 \pm 5$ & $2 \pm 2$ & $>0.000^{*}$ \\
\hline Sugar & 50 & $\mathrm{ND}$ & $\mathrm{ND}$ & $\mathrm{ND}$ & $\mathrm{ND}$ & $20 \pm 9.5$ & $0.001^{*}$ \\
\hline Glucose & 50 & $\mathrm{ND}$ & $\mathrm{ND}$ & $\mathrm{ND}$ & $8 \pm 4$ & $\mathrm{ND}$ & $0.001^{*}$ \\
\hline Water & 50 & $4 \pm 2$ & $2 \pm 0$ & $\mathrm{ND}$ & $2 \pm 1.73$ & $2 \pm 1$ & $0.04^{*}$ \\
\hline
\end{tabular}

*- Significant; NS-nonsignificant; ND - Not detected

The mean values of Adulterants in both raw and chilled milk samples from all five districts were compared and p-values were given in Table 3. In Visakhapatnam significant $p$-values were observed for Urea, Starch, Neutralizers, Detergents, Sugar, SMP, Glucose and Water. The pvalue was non-significant for $\mathrm{NaCl}$. In Srikakulam, significant P-values were obtained for Detergents, SMP and Glucose. The p-values were nonsignificant for Urea, Starch, Neutralizers and $\mathrm{NaCl}$. The p-values Sugar and Water were not obtained. In Vizianagaram significant $p$-values were observed for
$\mathrm{NaCl}$ and Water. The p-values were nonsignificant for Urea, Starch, Neutralizers and Detergents. The $\mathrm{p}$ - values were not reported for Sugar, SMP and Glucose. In East Godavari significant p-values were obtained for Detergents, $\mathrm{NaCl}$, Glucose and Water. The $\mathrm{p}$ - values were nonsignificant for Urea, Starch and Neutralizers and not reported for Sugar and SMP. In West Godavari p-values were significant for Detergents, $\mathrm{NaCl}$, Sugar and Water. The p-values were nonsignificant for Starch and Neutralizers and not obtained for Urea, SMP and Glucose. 


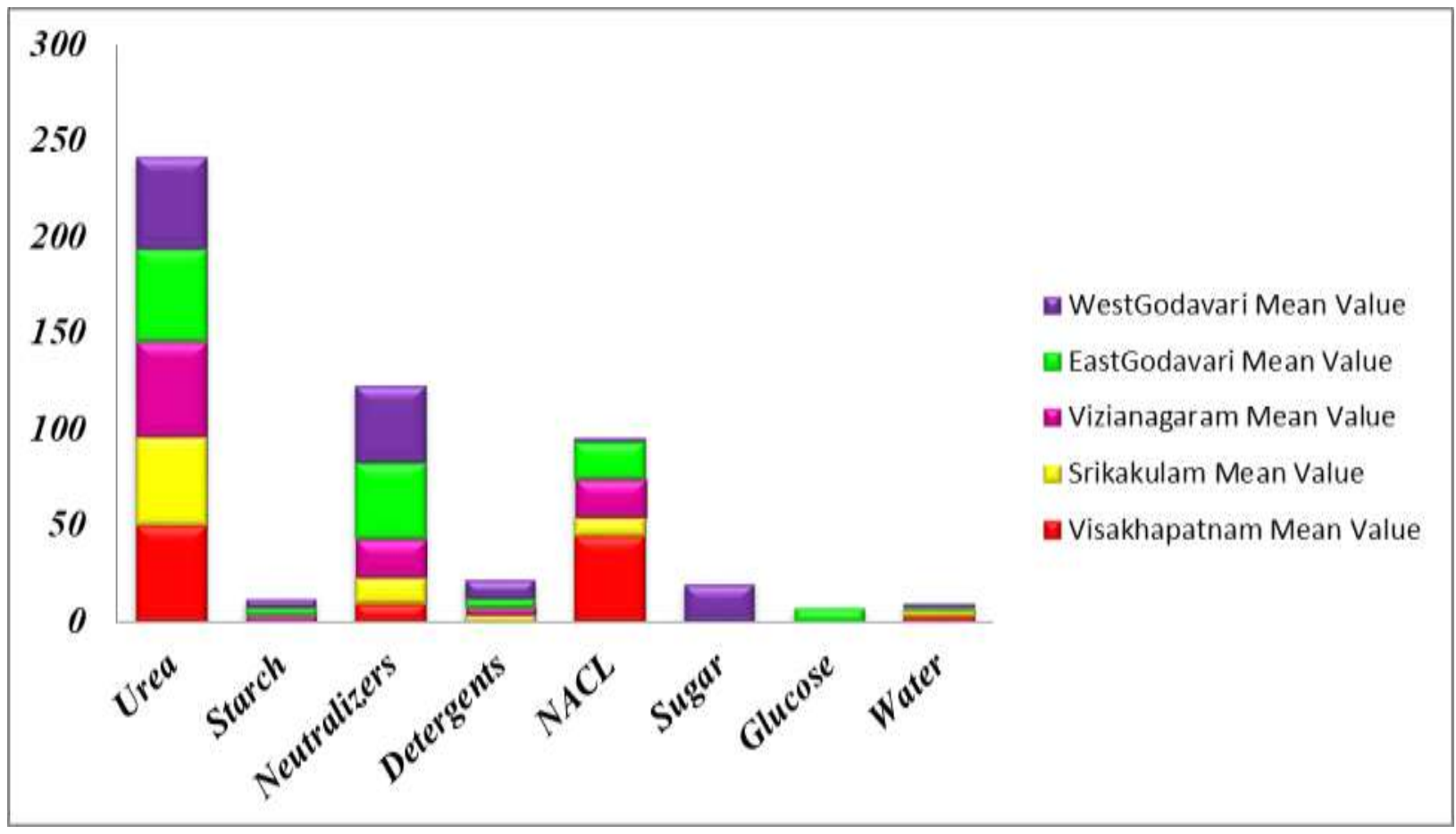

Figure 2: Mean values of adulterants of chilled milk samples in various regions

Table 3: Comparison of adulterants in positive raw and chilled milk samples

\begin{tabular}{|c|c|c|c|c|c|c|c|c|c|}
\hline $\begin{array}{l}\text { Name of the } \\
\text { region }\end{array}$ & Urea & Starch & Neutralizers & Detergents & $\mathrm{NaCl}$ & Sugar & SMP & Glucose & Water \\
\hline Vishakaptnam & $0^{*}$ & $0.003 *$ & $0.020 *$ & $0.011 *$ & 0.217 & $0.01 *$ & $0.002 *$ & $0.015^{*}$ & $0.01 *$ \\
\hline Srikakulam & $0.191^{\mathrm{NS}}$ & $0.057^{\mathrm{NS}}$ & $1.0^{\mathrm{NS}}$ & $>0.0001 *$ & 0.678 & - & $>0.001 *$ & $0.015^{*}$ & - \\
\hline Vizianagaram & $0.057^{\mathrm{NS}}$ & $1.0^{\mathrm{NS}}$ & $0.082^{\mathrm{NS}}$ & $0.120^{\mathrm{NS}}$ & $0.023 *$ & - & - & - & $0.012 *$ \\
\hline EastGodavari & $0.561^{\mathrm{NS}}$ & $0.120^{\mathrm{NS}}$ & $0.116^{\mathrm{NS}}$ & $0.026^{*}$ & $0.009 *$ & - & - & $0.026^{*}$ & $>0.00 *$ \\
\hline WestGodavari & - & $0.195^{\mathrm{NS}}$ & $1.00^{\mathrm{NS}}$ & $0.041 *$ & $0.004 *$ & $0.022 *$ & - & - & $0.002 *$ \\
\hline
\end{tabular}

*- Significant; NS-nonsignificant;

The mean values of adulterants in pasteurized milk samples were shown in Table 4. Starch was not detected in all types of pasteurized milk samples. Neutralizers were detected in all samples.
Detergents were not detected in homogenized toned milk. $\mathrm{NaCl}$ and Sugar were not detected in any of the samples. SMP was detected in all samples. Glucose and water were not 
detected in any of the pasteurized milk samples. The mean values of adulterants in pasteurized milk samples were shown in figure 3. The adulterants present in raw and chilled milk samples respectively were more or less similar to the results presented by Chanda et al., (2012). A research study was carried out to analyze the adulteration of raw milk and other samples like tetra pack milk for presence of adulterant like starch and was detected in samples more than the standard limits. (Hassabo Adam, 2009). A study on the hygienic status of milk in educational institutions and public places of Faisalabad, Pakistan was carried out by physical examination. The study of chemical composition, hygienic status and adulterants of milk samples was reported that the quality of milk samples was not up to the standards (Faraz et al., 2013).

Table 4: Mean values of adulterants in positive pasteurized milk samples

\begin{tabular}{|c|c|c|c|c|c|c|}
\hline $\begin{array}{c}\text { Name of } \\
\text { adulterant }\end{array}$ & $\begin{array}{c}\text { Total } \\
\text { number of } \\
\text { samples }\end{array}$ & TM & HTM & DTM & FCM & STD \\
\hline Neutralizers & 50 & $3.666 \pm 0.57$ & $4.6 \pm 0.57$ & $6.3 \pm 1.52$ & $2.6 \pm 0.57$ & $4.3 \pm 1.15$ \\
\hline Detergents & 50 & $0.66 \pm 0.57$ & ND & $0.6 \pm 0.3$ & $0.6 \pm 0.33$ & $0.66 \pm 0.57$ \\
\hline NaCl & 50 & ND & ND & ND & ND & ND \\
\hline Sugar & 50 & ND & ND & ND & ND & ND \\
\hline SMP & 50 & $15 \pm 5$ & $26.6 \pm 2.8$ & $25 \pm 5$ & $9.3 \pm 1.15$ & $6 \pm 1.73$ \\
\hline Glucose & 50 & ND & ND & ND & ND & ND \\
\hline Water & 50 & ND & ND & ND & ND & ND \\
\hline
\end{tabular}

*- Significant; ND -not detected; TM- Toned milk HTM- Homogenized Toned milk DTM- Double toned milk FCM-Full cream milk STD- standardized milk 


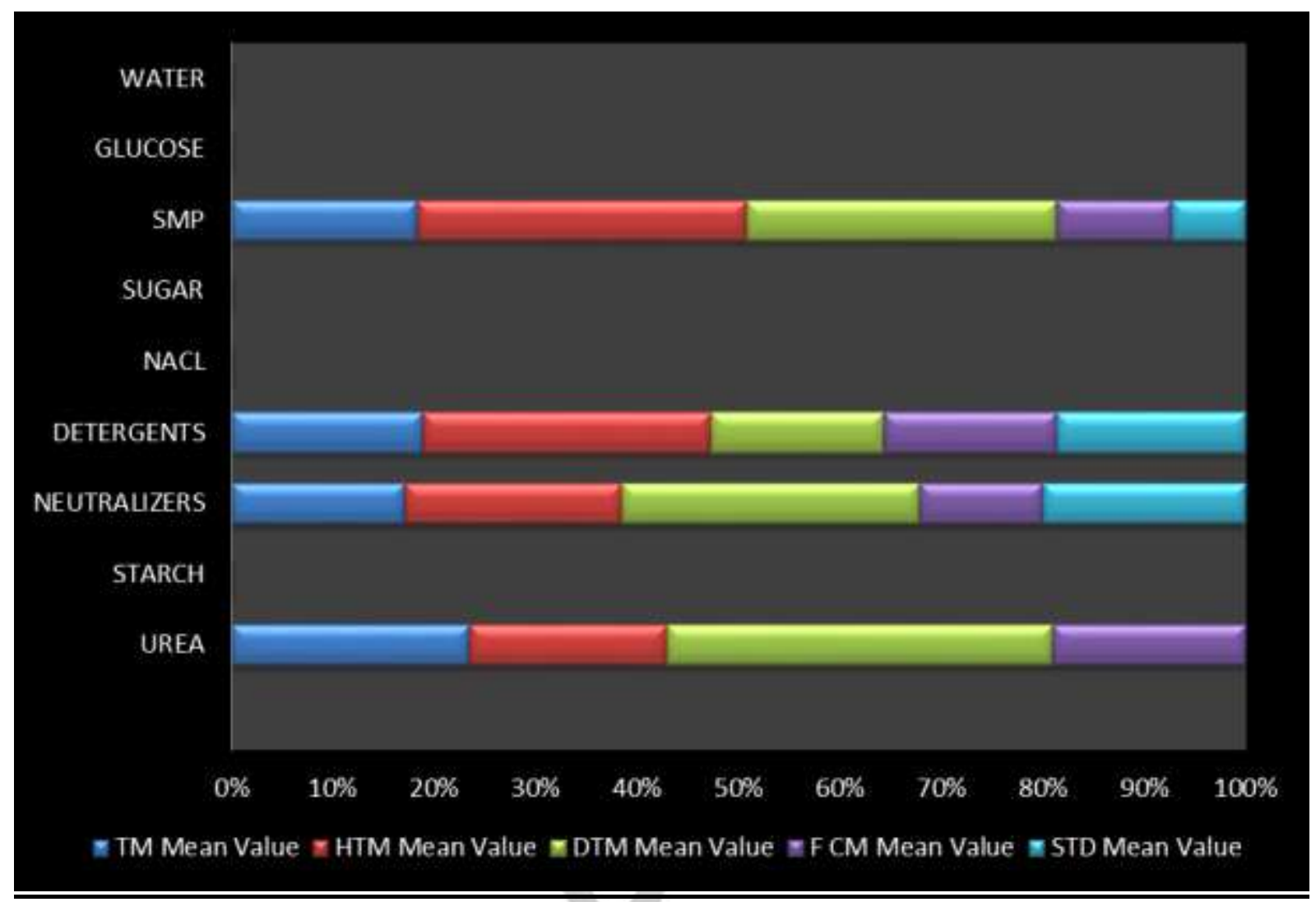

Figure 3: Mean values of adulterants of pasteurized milk samples in various regions

Analyses of Vendor's milk samples

The vendor's milk samples were analyzed for presence of specific pathogens, Aflatoxin MI and antibiotic residues. Standard plate count was also carried out. The number of samples collected was 50 and the mean values of various analyses were given in table 5 . These mean values indicate the poor

Table 5: Mean values of specific pathogens, standard plate count, aflatoxinM1 and antibiotic residues in vendor's milk samples

quality of Vendor's milk samples. The Mean values of specific pathogens, standard plate count, aflatoxinM1 and antibiotic residues in vendor's milk samples were shown in figure 4. The mean values of pesticide residues, heavy metal residues and adulterants in vendor's milk samples were given in table 6 and figure 5 . 


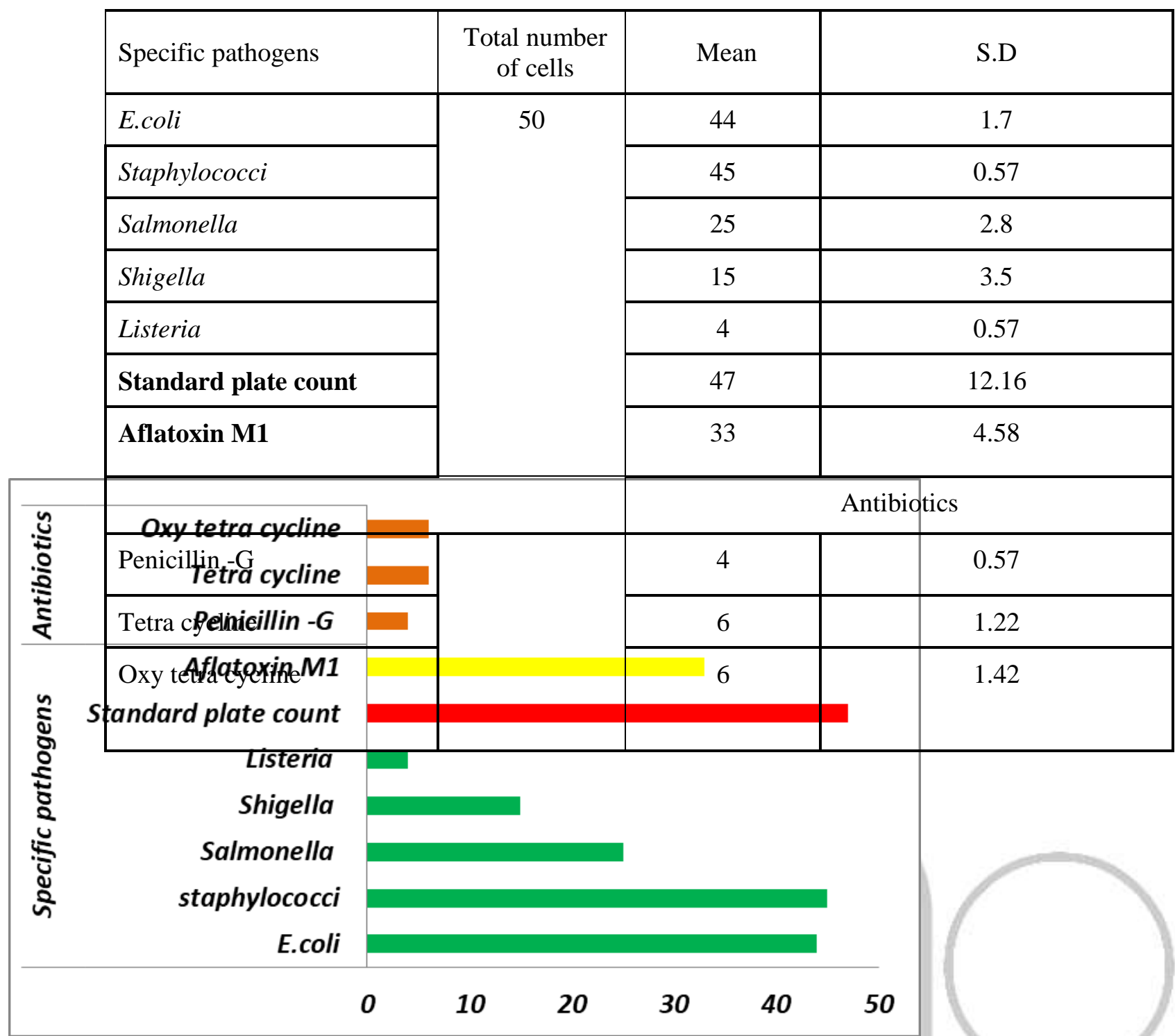

Figure 4: Mean values of specific pathogens, standard plate count, aflatoxinM1 and antibiotic residues in vendor's milk samples

Table 6: Mean value of pesticide residues, heavy metal residues and adulterants in vendors milk samples

\begin{tabular}{|l|c|c|}
\hline \multicolumn{1}{|c|}{ Pesticide residues } & Mean & S.D. \\
\hline Lindane & 40 & 3.6 \\
\hline Endosulfan & 50 & 4.61 \\
\hline Chlorane & 40 & 1.52 \\
\hline Heptachlor & 43 & 8.11 \\
\hline Methoxy chlorane Heavy metal residues & 7.93 \\
\hline \multicolumn{2}{|c|}{40} & 4.58 \\
\hline Lead & 30 & 6.083 \\
\hline Arsenic & 36 & 4.9 \\
\hline Zinc & \multicolumn{2}{|c|}{} \\
\hline
\end{tabular}




\begin{tabular}{|l|c|c|}
\hline Mercury & 2 & 0.97 \\
\hline Urea & 46 & 2.12 \\
\hline Starch & 23 & 1.76 \\
\hline Neutralizer & 43 & 6 \\
\hline Detergents & 4 & 0.61 \\
\hline NaCl & 33 & 1 \\
\hline Sugar & 43 & 8.66 \\
\hline Glucose & 40 & 6.5 \\
\hline Water & 35 & 1.73 \\
\hline
\end{tabular}

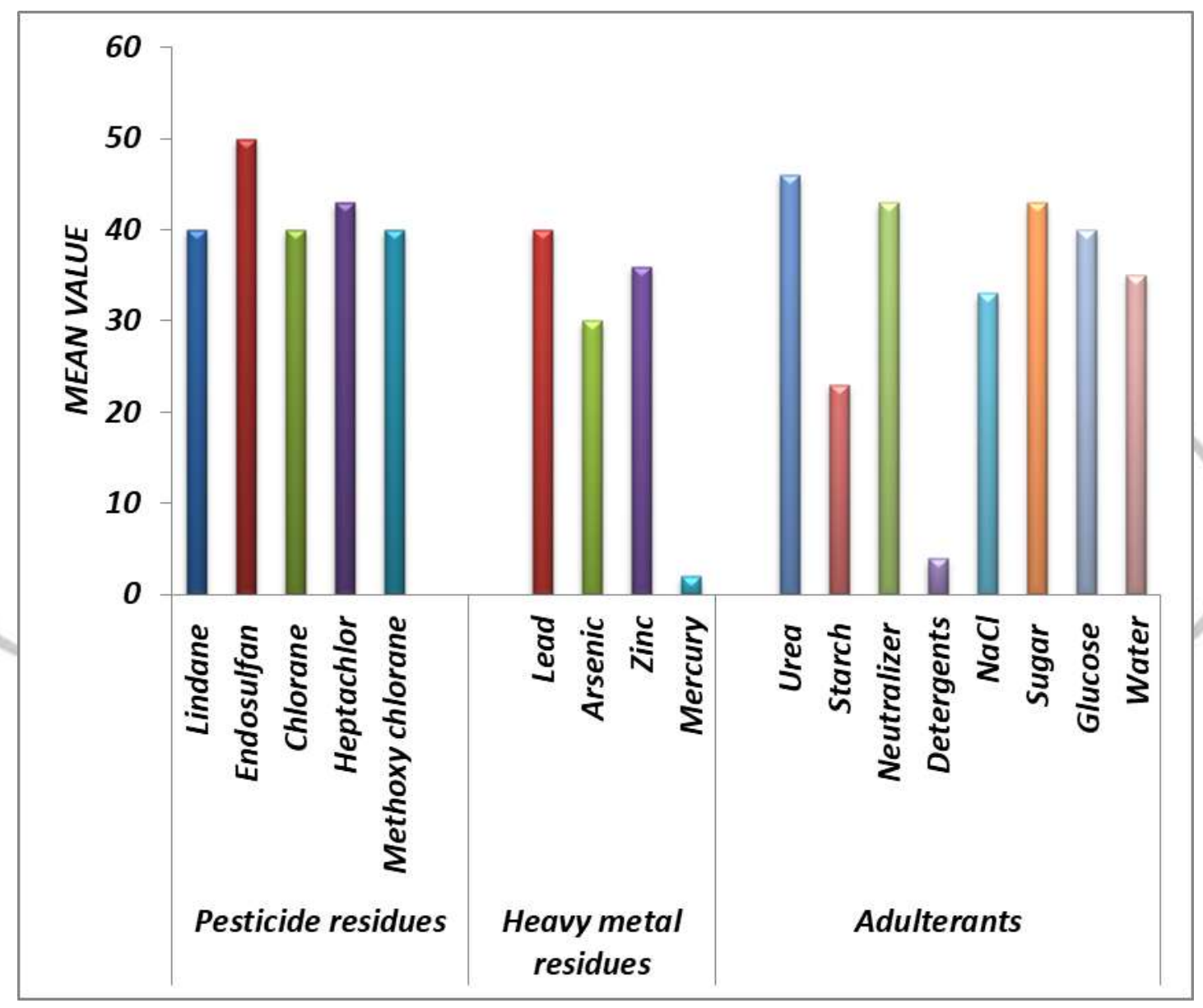

Figure 5: Mean values of pesticide residues, heavy metal residues and adulterants in vendor's milk samples

Table 7: Standard Values established by FSSAI for various parameters

\begin{tabular}{|l|l|}
\hline Name of the parameters & FSSAI Standard - 2011 \\
\hline Arsenic & $0.1 \mathrm{ppm} / \mathrm{w}$ \\
\hline Lead & $0.2 \mathrm{ppm} / \mathrm{w}$ \\
\hline Zinc & $50($ not less than $25.0 \mathrm{ppm} / \mathrm{w})$ \\
\hline
\end{tabular}




\begin{tabular}{|l|l|}
\hline Mercury & $1.0 \mathrm{ppm} / \mathrm{w}$ \\
\hline Aflotoxin M1 & $0.5 \mu \mathrm{g} / \mathrm{kg}$ \\
\hline Antibiotic Residues & \\
\hline Tetra Cycline & $0.1 \mathrm{ppm} / \mathrm{mg} / \mathrm{kg}$ \\
\hline Oxy Tetra Cycline & $0.1 \mathrm{ppm} / \mathrm{mg} / \mathrm{kg}$ \\
\hline Penicillin $-\mathrm{G}$ & $0.1 \mathrm{ppm} / \mathrm{mg} / \mathrm{kg}$ \\
\hline Pathogens & \\
\hline SPC/APC & 30000 CFU/ML $(10-3 * 30$ CFU/ML) \\
\hline E. coli & Absent $/ 0.1 \mathrm{ml}$ \\
\hline Staphylococcus aureus & Absent \\
\hline Salmonella & Absent $/ 25 \mathrm{ml} / \mathrm{gm}$ \\
\hline Shigella & Absent $/ 25 \mathrm{ml} / \mathrm{gm}$ \\
\hline Listeria spp & Absent $/ 25 \mathrm{ml} / \mathrm{gm}$ \\
\hline Pesticide residues & Tolerance limit mg/kg ppm \\
\hline methoxchlor & Not specified \\
\hline Endosulfan & $*$ Not Specified \\
\hline Hepatochlor & 0.15 \\
\hline Lindane & 0.01 \\
\hline
\end{tabular}

* Source: Food safety and standard (Contaminants, Toxins and Residues) Regulation - 2011

The standard values of pathogens, aflatoxin $M 1$, antibiotic residues, pesticide residues and heavy metal residues were given in table 7. Basing on comparison of values of current study with FSSAI standard values, the milk samples in all districts collected were can be described as poor quality.

\section{Conclusion}

Adulterants were detected in milk samples of five districts and significant $\mathrm{p}$ values were observed for neutralizers, detergents, $\mathrm{NaCl}$, sugar, glucose and water. The p-values were found to be non-significant for Urea and Starch. Presence of adulterants in milk affects the quality of milk. The comparison of mean values and $p$ - values of positive raw, chilled and pasteurized milk samples of current study with the standard values indicate that the milk samples collected from 5 coastal districts of Andhra Pradesh can be described as poor quality.

\section{References}

Ananya Debnath; S Banerjee; C Rai; A Roy (2015). Qualitative detection of adulterants in milk samples from kolkata and its suburban areas IMPACT:IJRANSS, 3(8), 81-88.
Awal Md. Shihabul, Amin Md. Ruhul Haque Md. Raihanul Kamal Md. Murtuza Hasan
S.M. Kamrul (2016) Evaluation of Physico- Chemical Properties and Detection Adulterants UHT Milk Samples Available in Bangladesh. International Research Journal of Biological Sciences, Vol. 5(2), International Science Community Association, 1-6, February , Available online at: www.isca.in, www.isca.me 
Awan A, Misbah N, lqbal A, Muhammad Ali $\mathbf{M}$, lqbal $\mathbf{R}(2014)$. A study on chemical composition and detection of chemical adulteration in tetra pack milk samples commercially available in Multan. Pak J Pharm Sci27: 183-186.

Chanda, T., Debnath, G.K., Hossain, M.E., Islam, M.A. and Begum, M.K (2012). Adulteration of raw milk in the rural areas of Barisal district of Bangladesh. Bangladesh journal of animal science, 41 (2): 112-115.

Faraz, A., M. Lateef, M. I. Mustafa, P. Akhtar, M. Yaqoob and Rehman S (2013). Detection of adulteration, chemical composition and hygienic status of milk supplied to various canteens of educational institutes and public places in Faisalabad, The Journal of Animal and Plant Sciences, 23(1): 119-124.

Hande Ashwini (2015). Analysis of adulteration of milk from various dairies in the different area of Amravati. Int. Res. J. of Sci. \& Engg.; 3 (1):12-14.

Hassabo Adam, A (2009). Milk adulteration by adding water and starch at Khartoum state. Pakistan Journal of Nutrition, 8 (4): 439-440.

Jivraj Makadiya and Astha Pandey (2015). Quality Assessment and Detection of Adulteration in Buffalo Milk Collected from Different Areas of Gandhinagar by Physico-Chemical Method. Int.J. PharmTech Res. 8(4), pp 602-607.

Mohit Kamthania, Jyoti Saxena, Komal Saxena, Sharma, D.K (2014). Milk Adulteration:Methods of Detection \& Remedial Measures. Int. J. Engg. and Technical Res, 1:2321-2869.

Ritu Tangri and Anshu S.Chatli (2014). Microbial quality and chemical adulterants evaluation in the raw and pasteurized milk. Asian Journal of Science and Technology Vol. 5, Issue 11, pp.716721, November.

Singuluri. H., Sukumaran MK (2014). Milk Adulteration in Hyderabad, India - A Comparative Study on the Levels of Different Adulterants Present in Milk. J. Chromatograph Separate Techniq5:212. doi:10.4172/2157-7064.1000212.

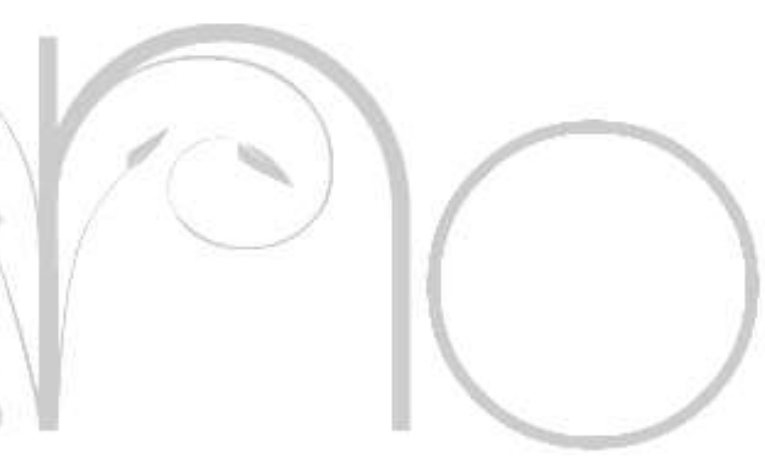

2020 November Edition |www.jbino.com | Innovative Association 